\title{
Changes in the Physico-Chemical Parameters of Water as a Result of Long-Term Contact with Biomass, on the Example of Pine Bark (Pinus sylvestris)
}

\author{
Tomasz Garbowski iD
}

Received: 26 January 2019/Accepted: 12 April 2019/Published online: 26 April 2019

(C) The Author(s) 2019

\begin{abstract}
Water encountering biomass can affect the change in its chemical composition and properties through the leaching process. In the leaching process, leachates are formed, and their composition depends on the type of biomass and the time of exposure to the solvent (water). The aim of the study was to analyze the influence of time of contact of water with biomass on changing the chemical composition of the leachates formed during long-term (counted in days) leaching of pine bark (Pinus sylvestris). Long-term leaching contributes to a loss of organic and inorganic compounds, and in this study, an intensive extraction of biomass components was noted from the first day of leaching. Along with the extension of the leaching time, values for electrical conductivity, concentration of mineral fraction (ashes), concentration of volatile matter, and concentration of total organic carbon significantly increased in the leachates. However, no linear relationship between the extension of the leaching time and the increase in the concentration of chlorides, sulfates, nitrogen, phosphorus, and other elements in the leachates was observed. This study will allow to better understand the impact of vegetation communities on the aquatic and terrestrial ecosystems, as well as help to provide adequate conditions of storage of biomass for technological purposes.
\end{abstract}

T. Garbowski $(\bowtie)$

Institute of Environmental Engineering, Wrocław University of Environmental and Life Sciences, Grunwaldzki Square 24,

50-363 Wrocław, Poland

e-mail: tomasz.garbowski@upwr.edu.pl
Keywords Biomass $\cdot$ Pine bark $\cdot$ Leaching process . Leachates composition

\section{Introduction}

Biomass is a complex mixture of organic and inorganic matter. It is defined as a heterogeneous mixture of the liquid and solid phases (Vassilev et al. 2012; Han et al. 2018). According to the Food and Agriculture Organization of the United Nations (FAO) (2016), the global forest area in 2015 was 3,999,134 hectares which makes wood one of the most widespread types of biomass in the world. A characteristic element of the tree is bark which constitutes from 10 to $20 \%$ of the dry matter of the trunk. These values depend mainly on the species of the tree, and in the case of pine bark, it is a value closer to $10 \%$ of the dry matter of the trunk (Filbakk et al. 2011; Shorohova and Kapitsa 2014). The bark constitutes the outer tissue of the tree and is exposed to pollution (Valentín et al. 2010), as well as the extraction effect of water. The bark of trees acts as a kind of filter for pollutants present in the atmosphere, which are spread in the environment under the influence of water.

The main components of plant biomass are cellulose, hemicellulose, and lignin, as well as mineral compounds contained in the ashes formed during biomass combustion, and extractives (Eom et al. 2012; Vassilev et al. 2012; Deng et al. 2013; Han et al. 2018). Pine bark, on average, contains $34-45 \%$ of lignin, $25 \%$ of cellulose, $15 \%$ of hemicellulose, $17 \%$ of extractives, and $5 \%$ of 
minerals (ashes). The main elements of biomass are $\mathrm{C}$, $\mathrm{O}, \mathrm{H}, \mathrm{N}, \mathrm{Ca}, \mathrm{K}, \mathrm{Si}, \mathrm{Na}, \mathrm{Mg}, \mathrm{Mn}, \mathrm{Fe}, \mathrm{Cl}, \mathrm{Al}, \mathrm{P}, \mathrm{S}$, and Ti (Chandrasekaran et al. 2012; Vassilev et al. 2012; Vassilev et al. 2015). Among these components, the largest share in the total weight of biomass is that of carbon (40-50\%), followed by oxygen (34-40\%) and hydrogen (5-6\%) (Valentín et al. 2010; Filbakk et al. 2011). They are a part of organic compounds that predominate in biomass. Other elements are macro- or microelements, and their concentration depends on the type of biomass. The content of inorganic matter in biomass varies in the range of $0.1-46 \%$ (Eom et al. 2012; Vassilev et al. 2012).

As a result of exposure of tree to water, both during its processing and under natural conditions (rainfall), leaching of components of biomass from its external layers occurs. In the natural environment, the removal of biomass components under the influence of water is of great importance in forest areas. They are densely wooded areas, and their substrate constitutes a litter which consists mainly of dead plant remains (leaves, needles, branches, bark, seeds, or fruit), as well as dead, fallen trees undergoing decomposition (Štrusowá et al. 2012). Plant tissues are not resistant to decomposition and leaching; a significant role in these processes is played by time counted in hours, days, and even years (Prescott 2010). In the leaching process and decomposition of biomass, extremely important parameters are also occurrence of the mobile and water-soluble forms of the components of biomass as well as its humidity (Prescott 2010; Vassilev and Vassileva 2016). The most mobile elements commonly occurring in biomass include $\mathrm{Ca}, \mathrm{Cl}, \mathrm{K}, \mathrm{Mg}, \mathrm{N}, \mathrm{Na}, \mathrm{P}$, and $\mathrm{S}$. The mobility of these elements is related to the moisture content of biomass by which they are completely or partially removed in the leaching process (Vassilev and Vassileva 2016). Harmful elements, such as $\mathrm{Al}, \mathrm{As}, \mathrm{Ba}, \mathrm{Co}, \mathrm{Cu}$, $\mathrm{Fe}, \mathrm{Mn}, \mathrm{Mo}, \mathrm{Pb}, \mathrm{Sr}, \mathrm{Ti}, \mathrm{V}$, and $\mathrm{Zn}$, may also be associated with the liquid phase of biomass (Werkelin et al. 2010; Vassilev et al. 2014; Vassilev et al. 2015). Mobile inorganic components can contribute to serious environmental problems such as soil salinity, pollution, and eutrophication of water, as well as poisoning of flora and fauna (Vassilev et al. 2015). The main phenomenon that occurs during leaching of biomass is reduction of inorganic compounds. This allows to significantly reduce the formation of ashes during thermal utilization of biomass, and to increase the share of volatile matter, which significantly improves the properties of biomass as a fuel (increase in calorific value) (Deng et al. 2013; Jiang et al. 2013; Yu et al. 2014; Wigley et al. 2016).

Water leaching is considered to be a cheap, fast, and effective method of pretreatment of biomass. Leaching is also occurred during the growth of biomass as a result of exposure to rainfall (Liu and Bi 2011). This causes a change in the composition of rainwater that goes to the ground and shallowly located groundwater. Chlorine $(\mathrm{Cl})$, potassium $(\mathrm{K})$, sodium $(\mathrm{Na})$, and phosphorus $(\mathrm{P})$ are leached in the highest amounts by using water, and in a measure also calcium $(\mathrm{Ca})$, sulfur (S), magnesium $(\mathrm{Mg})$, and iron (Fe) (Jensen et al. 2001a; Liu and Bi 2011; Vamvuka and Sfakiotakis 2011; Deng et al. 2013; Jiang et al. 2013; Yu et al. 2014). Studies show that during water leaching of biomass, some quantities of $\mathrm{N}$ and $\mathrm{Si}$ are extracted, as well as harmful elements such as $\mathrm{As}, \mathrm{Ba}, \mathrm{Co}, \mathrm{Cu}, \mathrm{Mo}, \mathrm{Pb}, \mathrm{Sr}, \mathrm{Ti}$, and V (Vassilev et al. 2012; Vassilev et al. 2014; Vassilev and Vassileva 2016).

Water does not remove insoluble inorganic compounds because these compounds are mostly bound, as the cations with active sites of lignin, cellulose, or hemicellulose, and in order to be removed, they require an acidic environment (Springer and Harris 1982; Liu and Bi 2011; Wigley et al. 2016). While water has an acidic character (for example acid rain), leaching is more effective in removing inorganic compounds; it also causes an increased loss of mass due to increased removal of organic matter (Liu and Bi 2011; Kröppl and Lanzerstorfer 2013; Asadieraghi and Wan Daud 2014; Wigley et al. 2016). This is adverse from the point of view of the use of biomass, e.g., for energy purposes (Liu and Bi 2011; Wigley et al. 2016). Moreover, acid leaching changes the structure of biomass due to the degradation of the long chains of polymeric organic compounds and infringes the crystalline structure of some minerals. As a result of acid leaching, there are serious environmental problems resulting from heavily contaminated and acidified leachates (Liu and Bi 2011; Jiang et al. 2013; Chen et al. 2018).

The knowledge about components extracted from pine bark during the long-term leaching process with water is crucial due to the use of this bark as a substrate for algal cultivation. This cultivation is conducted as part of separate studies. This knowledge may contribute to a reduction in high cultivation costs and facilitate the separation of these microorganisms from the liquid medium, which with the current technology is the main challenge in the open systems as well as in closed 
photobioreactors (Rawat et al. 2011; Boelee et al. 2011; Prajapati et al. 2013; Garbowski et al. 2017). The substances extracted from the bark may have a significant impact on the growth and properties of algae proliferated on the surface of this substrate. The study is focused on analyzing the influence of the time of leaching with distilled water on the chemical composition of the leachates obtained and their possible impact on the environment. According to studies by other authors, sufficient time to obtain the maximum effectiveness of biomass leaching is 2-4 h (Liu and Bi 2011; Deng et al. 2013; Wigley et al. 2016). In this study, it was investigated whether after a considerable extension of this time (up to 10 days) there will be further changes in the chemical composition of the leachates, and partly of the biomass.

\section{Materials and Methods}

\subsection{Experimental Setup and Operation}

The reason for choosing bark as a material for research was its property as a porous, outer layer of a tree (susceptibility to pollution and the impact of weather conditions). On the other hand, Scots pine (Pinus sylvestris) is one of the dominant species of the trees in the temperate climate of Europe and Asia. The bark was delivered in bags, in prefragmented form (few-centimeter fragments), and came from different parts of trees. Before the leaching process, the bark was mechanically cleaned of residues of sand, soil, and dust and then dried at $105 \pm 2{ }^{\circ} \mathrm{C}$ for $24 \mathrm{~h}$. After drying, a part of the bark was ground by querns up to a grain size of $\leq 5 \mathrm{~mm}$.

The experiment was conducted in glass laboratory flasks with capacity of $1000 \mathrm{ml}$. To each flask, pulverized bark in the amount of $30 \mathrm{~g}$ was introduced and then poured over with distilled water at a ratio of 1:30 $\left(900 \mathrm{ml} \mathrm{H}_{2} \mathrm{O}\right)$. The flasks were secured with a cap to prevent water evaporation during the leaching process and shaken in order to thoroughly mix the bark with distilled water before leaving them for the leaching. Samples prepared in that manner were put in a dark place for leaching at ambient temperature. Different times of leaching were adopted for each sample: sample 1-leaching for 1 day, sample 2leaching for 2 days, sample 3-leaching for 5 days, and sample 4-leaching for 10 days.
After the specified leaching time, the bark was drained, and the leachates were analyzed to determine parameters such as chemical composition, $\mathrm{pH}$, electrical conductivity (EC), dry residue, content of volatile matter, concentration of total nitrogen $\left(\mathrm{N}_{\text {total }}\right)$, Kjeldahl nitrogen $\left(\mathrm{N}_{\mathrm{Kjeldahl}}\right)$, organic nitrogen, ammonium nitrogen $\left(\mathrm{NH}_{4}{ }^{+}\right)$, nitrates $\left(\mathrm{NO}_{3}{ }^{-}\right)$, nitrites $\left(\mathrm{NO}_{2}{ }^{-}\right)$, total phosphorus $\left(\mathrm{P}_{\text {total }}\right)$, chlorides $\left(\mathrm{Cl}^{-}\right)$, sulfates $\left(\mathrm{SO}_{4}{ }^{2-}\right)$, and total organic carbon (TOC).

\section{$2.2 \mathrm{pH}$ and Electrical Conductivity}

The $\mathrm{pH}$ of the analyzed leachates was determined using the potentiometric method in accordance with the PNEN ISO 10523:2012 standard (2012), and electrical conductivity (EC) with the conductometric method according to the PN-EN 27888:1999 standard (1999). For the analysis of both parameters, $100-\mathrm{ml}$ samples of the leachates were collected.

\subsection{ICP-OES Analysis}

The leachates after the leaching of pine bark and crude bark (bark before the leaching) were subjected to ICPOES (inductively coupled plasma-optical emission spectroscopy) analysis with the use of the Thermo Scientific iCAP 7000 Series ICP-OES apparatus equipped with an autosampler. The results obtained were generated by Qtegra Intelligent Scientific Data Solution software. The crude bark (the weight of a single sample of the bark- $0.1 \mathrm{~g}$ ) and the leachates (the volume of a single sample - $50 \mathrm{ml}$ ), before the analysis of elemental composition, were subjected to the mineralization process with the use of a mixture of acids: concentrated $\mathrm{H}_{2} \mathrm{SO}_{4}, 60 \% \mathrm{HClO}_{4}$, and concentrated $\mathrm{HNO}_{3}$, at a ratio of $1: 4: 10$, at temperature of about $600{ }^{\circ} \mathrm{C}$. The leachates in non-mineralized form were also analyzed by the ICPOES method. The ICP-OES apparatus analyzed the cations of the following elements: $\mathrm{Pb}, \mathrm{Cd}, \mathrm{Cr}, \mathrm{Cu}, \mathrm{Ni}$, $\mathrm{Ag}, \mathrm{Al}, \mathrm{B}, \mathrm{Ba}, \mathrm{Bi}, \mathrm{Ca}, \mathrm{Fe}, \mathrm{Ga}, \mathrm{In}, \mathrm{K}, \mathrm{Li}, \mathrm{Mg}, \mathrm{Mn}, \mathrm{In}, \mathrm{Sr}$, $\mathrm{Tl}, \mathrm{Zn}, \mathrm{Co}, \mathrm{K}$, and $\mathrm{Na}$ for their presence in the test samples. Each sample for the ICP-OES analysis had a volume of $15 \mathrm{ml}$, and the apparatus performed three replicates for an individual sample. The result obtained was the average of the concentrations of a given element from the three replicates. In addition, the results were converted from parts per million to milligrams per gram of dry weight. 


\subsection{Dry Residue}

Dry residue was analyzed from the volume of the leachates of $100 \mathrm{ml}$ which was initially evaporated on a laboratory water bath and then combusted at $550{ }^{\circ} \mathrm{C}$ for about $2 \mathrm{~h}$ until the mineral fraction was obtained. Then, the dry residue, volatile matter, and mineral fraction were determined according to the following relationships:

- Dry residue = weight of the evaporating dish after the evaporation of the leachate - weight of the empty evaporating dish

- Volatile matter = weight of the evaporating dish after the evaporation of the leachate - weight of the evaporating dish after the burning of the dry sample

- Mineral fraction (ashes) = weight of the evaporating dish after the burning of the dry sample - weight of the empty evaporating dish

\subsection{Total Nitrogen and Total Phosphorus}

Analysis of the concentration of nitrogen was limited to the determination of the following parameters (Table 1).

Total nitrogen was determined as the sum of the Kjeldahl nitrogen, nitrates, and nitrites. The determination of total phosphorus was made by the spectrophotometric method with ammonium molybdate in accordance with the PN-EN ISO 6878:2006 standard (2006). The volume of the samples in the analysis of nitrogen and phosphorus was dependent on the concentration of the individual component in the leachate and ranged from 10 to $40 \mathrm{ml}$.

\subsection{Chlorides and Sulfates}

Chlorides were determined in samples with a volume of $10 \mathrm{ml}$ by titration with $\mathrm{AgNO}_{3}$ in the presence of potassium chromate salt as an indicator (Mohr method), according to the PN-ISO 9297:1994 standard (1994).

Sulfates (VI) were determined in the leachates in accordance with the PN-ISO 9280:2002 standard (2002), by using the gravimetric method with barium chloride. Samples with the volume of $100 \mathrm{ml}$ were collected for the analysis.

\subsection{Total Organic Carbon}

Determination of this parameter was performed by using the total organic carbon (TOC) Sievers InnovOx Laboratory Analyzer which was coupled to the autosampler for sampling, due to which the measurement was fully automated. This device uses the technology of supercritical water oxidation (SCWO). The leachate samples used in the determination of TOC had a volume of $40 \mathrm{ml}$ and were not subjected to prior filtration (except for draining of the bark after the leaching process).

\section{Results and Discussion}

\section{$3.1 \mathrm{pH}$ and Electrical Conductivity of the Leachates}

The leachate after the leaching of pine bark was characterized by a significantly lower $\mathrm{pH}$ compared to distilled water $(\mathrm{pH}=7.48)$ which was used for the leaching. Figure 1 shows a change in the reaction after the first day of leaching, and the value of $\mathrm{pH}$ was 5.16. A similar value was maintained on the second and fifth days of leaching $(\mathrm{pH}=5.15)$, while after 10 days, the $\mathrm{pH}$ of the leachate slightly increased to 5.30 . Studies conducted by Vassilev et al. (2012) show that the leaching of biomass causes the acidification of the leachates. Those authors showed that the $\mathrm{pH}$ of the leaching of different types of biomass varies in the range of 4-6 (Vassilev et al. 2012). The reaction of biomass depends on the content of organic matter and composition of the mobile phase

Table 1 The methods for determination of various forms of nitrogen in the leachates after leaching of pine bark

\begin{tabular}{llll}
\hline No. & Parameter & Name of the method & Standard \\
\hline 1 & Kjeldahl nitrogen & Specific method & PN-EN 25663:2001 (2001) \\
2 & Nitrates & Spectrophotometric method & PN-82C-04576/08 (1982) \\
3 & Nitrites & Spectrophotometric method & PN-EN 26777:1999 (1999) \\
4 & Ammonium nitrogen & Spectrophotometric method & PN-ISO 7150-1:2002 (2002) \\
5 & Organic nitrogen & Computational method & PN-73/C04576-14 (1973) \\
\hline
\end{tabular}


Fig. 1 The changes in $\mathrm{pH}$ and electrical conductivity of the leachates after different times of leaching of pine bark with distilled water

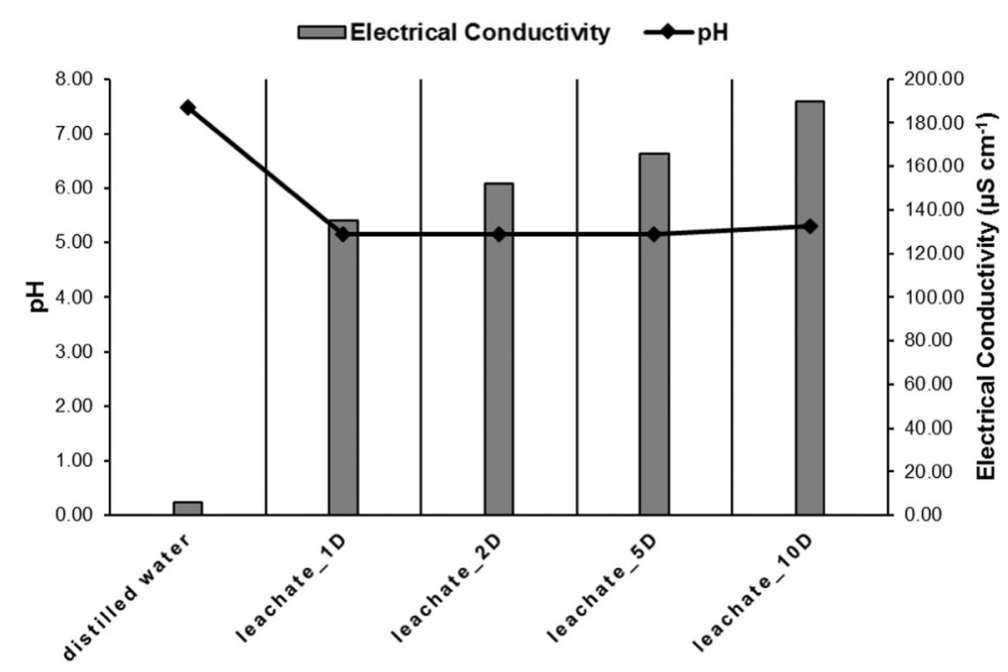

containing elements such as $\mathrm{S}, \mathrm{Cl}, \mathrm{Na}, \mathrm{Ca}, \mathrm{K}$, and others which may affect the acidic or alkaline reaction. The reaction affects the solubility of biomass components, and its too low value can be a serious problem due to increased solubility of harmful components such as $\mathrm{Cu}$, $\mathrm{Pb}, \mathrm{Zn}, \mathrm{Ni}, \mathrm{As}, \mathrm{Al}, \mathrm{Fe}$, and $\mathrm{Cr}$ (Xie et al. 2015; Vassilev and Vassileva 2016). In an acidic environment of leaching, the solubility of calcium oxalate which occurs particularly in the bark of the tree increases (Vassilev et al. 2014). Under acidic conditions, a part of the cellulose and hemicellulose contained in the biomass is converted to water-soluble products (e.g., amorphous organic compounds) (Vassilev et al. 2012; Kalogiannis et al. 2015). This contributes to an intensification of the removal of organic compounds from biomass. Water with a low $\mathrm{pH}$ value brought to the soil may cause acidification as well as affect the biodiversity of microorganisms, including microorganisms responsible for the decomposition of cellulosic biomass (Štrusowá et al. 2012).

The analysis of changes in the electrical conductivity of the leachates after the leaching of pine bark (Fig. 1) indicates that after the first day of leaching the EC increased significantly $\left(135.27 \mu \mathrm{S} \mathrm{cm}^{-1}\right)$ in relation to that of distilled water $\left(6.10 \mu \mathrm{S} \mathrm{cm}^{-1}\right)$. In the subsequent samples, the electrical conductivity increased and for the samples after 2, 5, and 10 days of leaching it was $151.94 \mu \mathrm{S} \mathrm{cm}{ }^{-1}, 165.66 \mu \mathrm{S} \mathrm{cm} \mathrm{cm}^{-1}$, and $189.92 \mu \mathrm{S} \mathrm{cm} \mathrm{cm}^{-1}$, respectively. This corresponds to an increase in the concentration of ions in the aqueous solution. The values of this parameter are as not as high as the results other researchers suggest, because according to Vassilev and Vassileva (2016), the electrical conductivity of the leachates after the leaching of biomass of terrestrial plants can range between 700 and $3500 \mu \mathrm{S} \mathrm{cm}^{-1}$. The lower values of EC obtained in this study compared to the literature data result from the high water/pine bark ratio (30:1) in conducted experiment. Nevertheless, it is worth noting the significant increase in the conductivity after the leaching of pine bark, which is related to the occurrence of water-soluble salts extracted from the biomass in the leachate (Yu et al. 2014). The most common salts which are easily leached from biomass include chlorides, sulfates, carbonates, nitrates, and phosphates (Vassilev et al. 2014). Along with them, among others, alkaline metals, chlorine, sulfur, nitrogen, and phosphorus pass into the solution, thereby reducing the concentration of the mineral fraction in the biomass (Yu et al. 2014). The analysis of the concentration of chlorides and sulfates in the leachate after the leaching of pine bark confirms the influence of these components on the increase in electrical conductivity, because chlorides and sulfates were found in the leachates after each fixed time of leaching. The electrical conductivity of the leachates depends not only on the presence of the soluble ions in the solution but also on organic matter (calcium oxalate or amorphous compounds) or changes in the $\mathrm{pH}$ (Vassilev and Vassileva 2016). Thus, the acid reaction observed in all samples of the leachates could lead to the increase in their conductivity.

\subsection{Content of Dry Residue, Volatile Matter,} and Mineral Fraction in the Leachates

The chart (Fig. 2) shows the differences in the content of solid particles in the leachates which have been leached from pine bark during the leaching with distilled water. 
Fig. 2 The concentration of mineral fraction (ashes), volatile matter (organic fraction), and dry residue in the leachates after different times of leaching of pine bark with distilled water
口Mineral fraction (ashes) $\quad$ QVolatile matter $\quad$ Dry residue

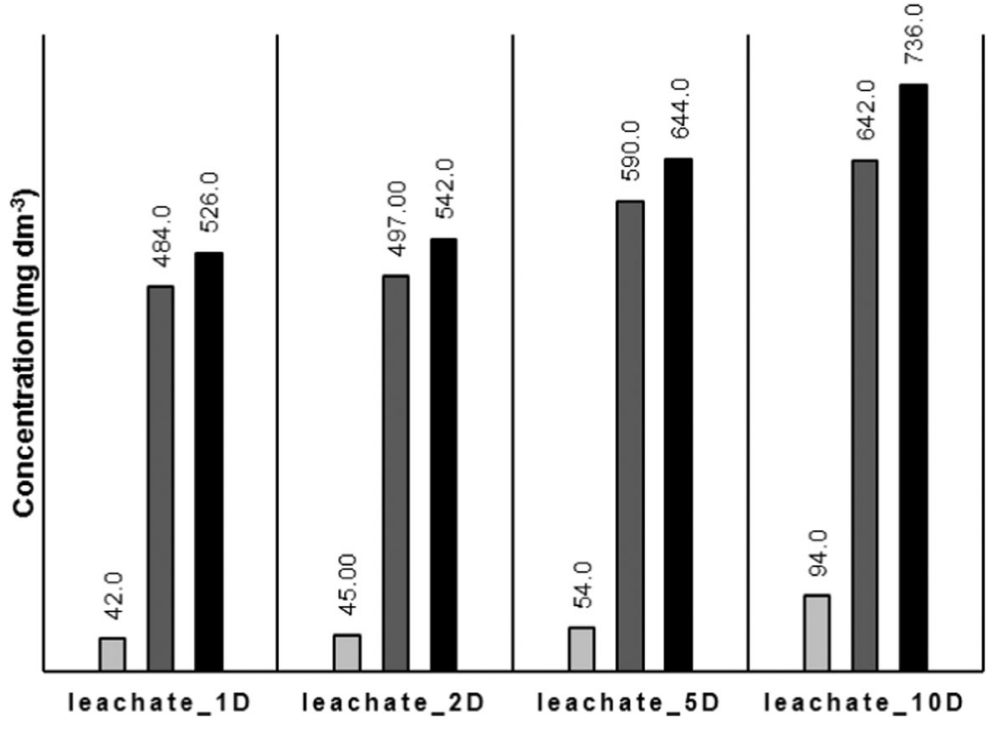

The dry residue in the leachates indicates an increase in the amount of solid fraction extracted from the bark along with the longer time of leaching $\left(526.0 \mathrm{mg} \mathrm{dm}^{-3}\right.$ after 1 day of leaching and $736.0 \mathrm{mg} \mathrm{dm}^{-3}$ after the 10th day of leaching). The dry residue in the leachates constitutes from 1.58 to $2.21 \%$ dry weight (all percentages in this paragraph were calculated based on the concentrations given in Table 2). This fraction includes both organic (volatile matter) (1.45-1.93\% dry weight) and mineral (ashes) (0.01-0.28\% dry weight) compounds. From the chart (Fig. 2), it appears that most of the dry residue in the leachates was volatile matter. This is due to the removal of organic compounds that at high temperature get converted to a gas form. The characteristic feature of the composition of biomass is a high concentration of volatile matter $(60-84 \%$ of the dry basis) (Vamvuka and Sfakiotakis 2011). The content of volatile matter in the leachate increased along with increasing time of leaching $\left(484.0 \mathrm{mg} \mathrm{dm}^{-3}\right.$ after the 1 st day of leaching and $642.0 \mathrm{mg} \mathrm{dm}^{-3}$ after 10 days of leaching). The compounds in biomass are characterized by high volatility due to the increased hydrogen content

Table 2 The concentration of the measured parameters in the non-mineralized leachates $\left(\mathrm{mg} \mathrm{g}_{\mathrm{DW}}{ }^{-1}\right)$

\begin{tabular}{|c|c|c|c|c|}
\hline Parameter & Leachate_1D & Leachate_2D & Leachate_5D & Leachate_10D \\
\hline Ashes & 1.260 & 1.350 & 1.620 & $2.820^{\mathrm{a}}$ \\
\hline Volatile matter & 14.520 & 14.910 & 17.700 & $19.260^{\mathrm{a}}$ \\
\hline Dry residue & 15.780 & 16.260 & 19.320 & $22.080^{\mathrm{a}}$ \\
\hline Chlorides & 0.600 & $0.660^{\mathrm{a}}$ & 0.510 & 0.600 \\
\hline Sulfates $^{b}$ & 0.172 & 0.189 & 0.153 & $0.203^{\mathrm{a}}$ \\
\hline Kjeldahl nitrogen ${ }^{\mathrm{b}}$ & 0.180 & $0.212^{\mathrm{a}}$ & 0.130 & 0.121 \\
\hline $\mathrm{NH}_{4}{ }^{\mathrm{b}}$ & 0.019 & 0.003 & 0.001 & $0.009^{\mathrm{a}}$ \\
\hline $\mathrm{NO}_{3}{ }^{\mathrm{b}}$ & $0.028^{\mathrm{a}}$ & 0.024 & $0.028^{\mathrm{a}}$ & 0.023 \\
\hline Organic nitrogen ${ }^{\mathrm{b}}$ & 0.161 & $0.209^{\mathrm{a}}$ & 0.130 & 0.112 \\
\hline Total nitrogen ${ }^{\mathrm{b}}$ & 0.208 & $0.236^{\mathrm{a}}$ & 0.158 & 0.144 \\
\hline Total phosphorus ${ }^{\mathrm{b}}$ & 0.065 & 0.080 & $0.087^{\mathrm{a}}$ & 0.069 \\
\hline TOC & 7.200 & 7.710 & $8.190^{\mathrm{a}}$ & 7.950 \\
\hline
\end{tabular}

${ }^{a}$ The highest value of parameter in the leachate

${ }^{\mathrm{b}}$ Values converted into milligrams of pure ingredient per gram of dry weight 
in relation to carbon. Carbon $(\mathrm{C})$ and hydrogen $(\mathrm{H})$ mostly form low molecular weight aromatic and aliphatic hydrocarbons and their derivatives, which together with other extractives form a part of dissolved organic matter (Leenheer and Croué 2003; Tan and Lagerkvist 2011; Miranda et al. 2012; Vassilev et al. 2015). These compounds are decomposed into volatile compounds at a sufficiently high temperature (Tan and Lagerkvist 2011). The dry residue containing volatile matter can be used in the pyrolysis process or as valuable chemical additives (Kalogiannis et al. 2015).

Analyzing the mineral residues (ashes) in the leachates, it can be found that extending the time of leaching increases the efficiency of removing solid inorganic particles. After the first day of leaching, the mineral fraction content was $42 \mathrm{mg} \mathrm{dm}^{-3}$ and after ten days of leaching the concentration of ashes was over 2 times higher $\left(94 \mathrm{mg} \mathrm{dm}^{-3}\right)$. Fragmentation enhances the processes of demineralization and decomposition of bark (Miranda et al. 2012; Shorohova and Kapitsa 2014). The pine bark used in the experiment was a mixture of fragments with diameter $\leq 5 \mathrm{~mm}$. Due to constant contact with the external environment, the bark is often contaminated with soil and dust particles from the air which penetrate its porous structure. It causes an increase in the total content of inorganic compounds (including ashes). Bark may contain even five times more ashes than wood (Filbakk et al. 2011; Miranda et al. 2012; Vassilev et al. 2012). Removal of the mineral fraction from biomass significantly improves its properties as a fuel, especially during combustion. It allows to improve the ratio of the combustible to non-combustible fraction, which increases the weight of the fuel while reducing the calorific value (Klasnja et al. 2002; Vassilev et al. 2015). Through the reduction of ashes, the risk of slagging, agglomeration, fouling, and corrosion in devices for the combustion of this type of fuel, as well as the emission of harmful compounds like dioxins and furans, decreases (Jiang et al. 2013; Yu et al. 2014; Vassilev and Vassileva 2016).

Despite the removal of certain amounts of ashes from the pine bark during leaching with water, these compounds do not pose a significant threat to the environment due to their insoluble nature. Moreover, Liu and Bi (2011) found that, in the case of pine bark, leaching with clean water does not remove large amounts of mineral components, compared to leaching with acidic solutions. The reason is the low occurrence of inorganic matter in the form of water-soluble compounds (Liu and Bi 2011; Yu et al. 2014).
3.3 Concentration of Chlorides and Sulfates in the Leachates

Along with the extractives, chlorides and sulfates are leached from the biomass, which belong to the so-called autogenic compounds that constitute the largest group of compounds (apart from detritic) in natural biomass. Their intensive leaching is conditioned by the low resistance to weathering and leaching. However, these compounds can mix with organic matter and then they are not so easily removed. During the drying of biomass, the precipitation of chlorides and sulfates takes place, as well as of other water-soluble salts (carbonates, nitrates, and phosphates). These compounds pass from the sparingly soluble forms to the easily soluble forms and thus can be removed even with clean water. At high moisture of biomass, more of these components go into solution (Vassilev et al. 2012; Vassilev et al. 2015). Werkelin et al. (2010) note that the whole or most of the chlorine and sulfur present in the water solution after the leaching of biomass occur in the form of $\mathrm{Cl}^{-}$and $\mathrm{SO}_{4}{ }^{2-}$. Chlorine can be removed from biomass already at the stage of its growth during rainfalls. Bark is particularly exposed to this, as the outer layer of the tree (Liu and Bi 2011; Deng et al. 2013). Chlorides and sulfates are the ash compounds that are responsible for their slagging, fouling, and agglomeration as well as harmful emissions $\left(\mathrm{SO}_{x}\right.$ and $\mathrm{Cl}$ ) and corrosion of the elements of the technological line for biomass combustion (Liu and Bi 2011; Vamvuka and Sfakiotakis 2011; Chandrasekaran et al. 2012; Yu et al. 2014; Vassilev et al. 2015). Thus, lowering the ash content (including chlorine and sulfur) due to the leaching allows to reduce the mentioned technological and environmental problems. Despite the low concentration of sulfates leached from pine bark (0.153-0.203 $\left.\mathrm{mg} \mathrm{g}_{\mathrm{DW}}{ }^{-1}\right)$, they may pose a threat to the environment especially in wooded areas with high content of sulfates in the atmosphere. Sulfates are characterized by high mobility; hence, they move quickly in the soil profile. Sulfates accumulated in the soil cause acidification. The other harmful effects of sulfate in the environment include its conversion in a process known as bacterial sulfate reduction. During this process, sulfates are converted to hydrogen sulfide, which is a highly toxic gas, and its release to the atmosphere is a problem (Moreno-Casas et al. 2009). Chlorine as an oxidant affects the decomposition of organic matter. Thus, the presence of chlorine in water with a high concentration of TOC (natural water) contributes to the 
release of bio-available organic carbon. This results in the development of microorganisms, including those hazardous to health (E. coli). As a result of the reaction of chlorine with organic compounds, organochlorine compounds with low biodegradability can also be formed (Raczyk-Stanisławiak et al. 2005). Chlorine is an important component of plants which is assimilated, among others, from rainwater. However, its excessive amounts may have a harmful impact on the development of most plants. In soil and water, chlorides cause an increase in the salinity (Świderska-Bróż and Kowal 2009).

Figure 3 shows the changes in the concentrations of chlorides and sulfates in the leachates after leaching of pine bark with distilled water. The trend of the changes is very similar in the case of both parameters, with the difference that the highest concentration of chlorides was observed in the leachate after 2 days of leaching $\left(22.00 \mathrm{mg} \mathrm{dm}^{-3}\right)$ and that of sulfates after 10 days of leaching $\left(20.32 \mathrm{mg} \mathrm{dm}^{-3}\right)$. On the contrary, the lowest values for both parameters were noted after 5 days of leaching $\left(\mathrm{Cl}^{-}-17.00 \mathrm{mg} \mathrm{dm} \mathrm{dm}^{-3}, \mathrm{SO}_{4}{ }^{2}\right.$ - $15.30 \mathrm{mg} \mathrm{dm}^{-3}$ ). The fluctuations in the concentrations of these anions are so slight within 10 days of leaching that it is difficult to clearly demonstrate the influence of the time of bark soaking on the increase in the efficiency of chloride and sulfate removal. This confirms the observation of other researchers that chlorine in the anion form is the fastest leached component from biomass, and that a longer time of leaching will not increase its concentration in the leachate (Jensen et al. 2001a, b; Liu and Bi 2011). Similarly, sulfur, whose forms in biomass are characterized by high mobility and susceptibility to leaching, is, next to $\mathrm{Cl}, \mathrm{K}, \mathrm{Na}$, and $\mathrm{P}$, the fastest removed component during leaching with water (Vassilev et al. 2012). Therefore, there are no significant differences in the concentration of sulfates in the leachates along with longer time of leaching.

\subsection{Concentration of the Different Forms of Nitrogen in the Leachates}

Nitrogen was present in the leachates in concentrations that did not allow to conclude that the longer time of leaching results in a more intense leaching of this component (Fig. 4). The highest value of total nitrogen was noted in the leachate after 2 days of leaching $\left(7.88 \mathrm{mg} \mathrm{dm}^{-3}\right)$. On the following days, the concentration of total nitrogen decreased (leachate after 5 days of leaching $-5.28 \mathrm{mg} \mathrm{dm}^{-3}$ ) and reached the lowest value after 10 days of leaching $\left(4.80 \mathrm{mg} \mathrm{dm}^{-3}\right)$. After the $1 \mathrm{st}$ day of leaching, the concentration of total nitrogen was $6.94 \mathrm{mg} \mathrm{dm}^{-3}$.

The dominant form of nitrogen in each of the analyzed leachates was organic nitrogen which constituted from 77.4 to $89.7 \%$ of total nitrogen, whereas ammonium nitrogen was found in the leachates in a small amount $\left(0.02-0.63 \mathrm{mg} \mathrm{dm}^{-3}\right)$. The other form of nitrogen in the leachate is nitrate nitrogen $\left(\mathrm{NO}_{3}{ }^{-}\right)$. The concentrations of this component were similar in each of the
Fig. 3 The concentration of chlorides and sulfates in the leachates after different times of leaching of pine bark with distilled water

\section{$\triangle$ Chlorides $\bullet$ Sulfates}

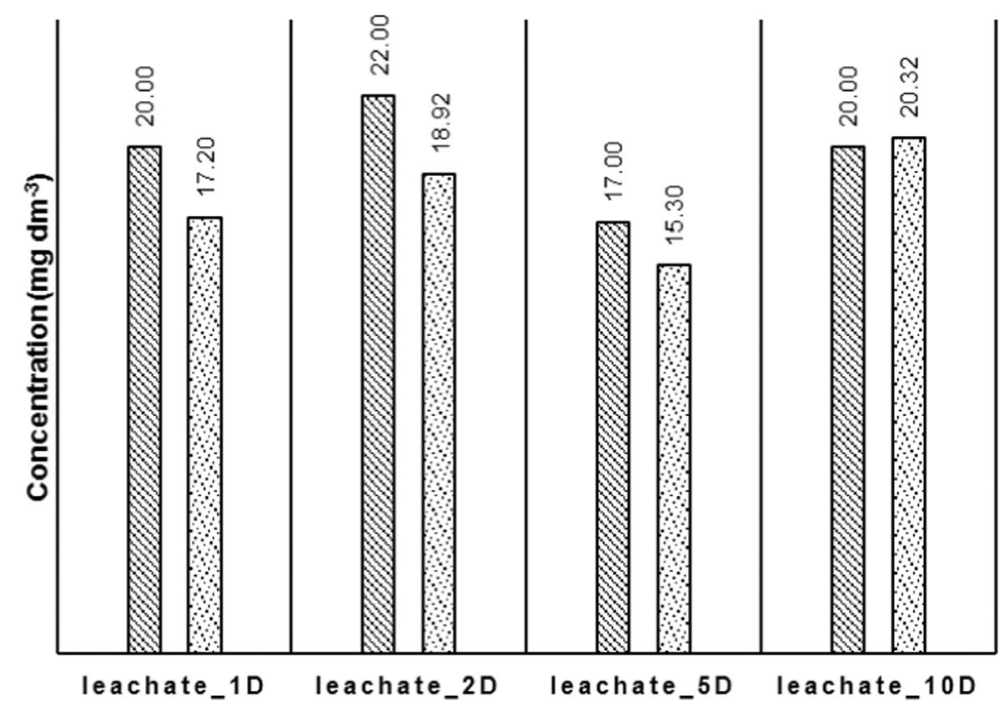


Fig. 4 The concentration of the different forms of nitrogen and total phosphorus in the leachates after different times of leaching of pine bark with distilled water
口Ammonium nitrogen $\square$ Nitrates
øKjeldahl Nitrogen $\quad$ Total Nitrogen
口Organic Nitrogen
\& Total Phosphorus

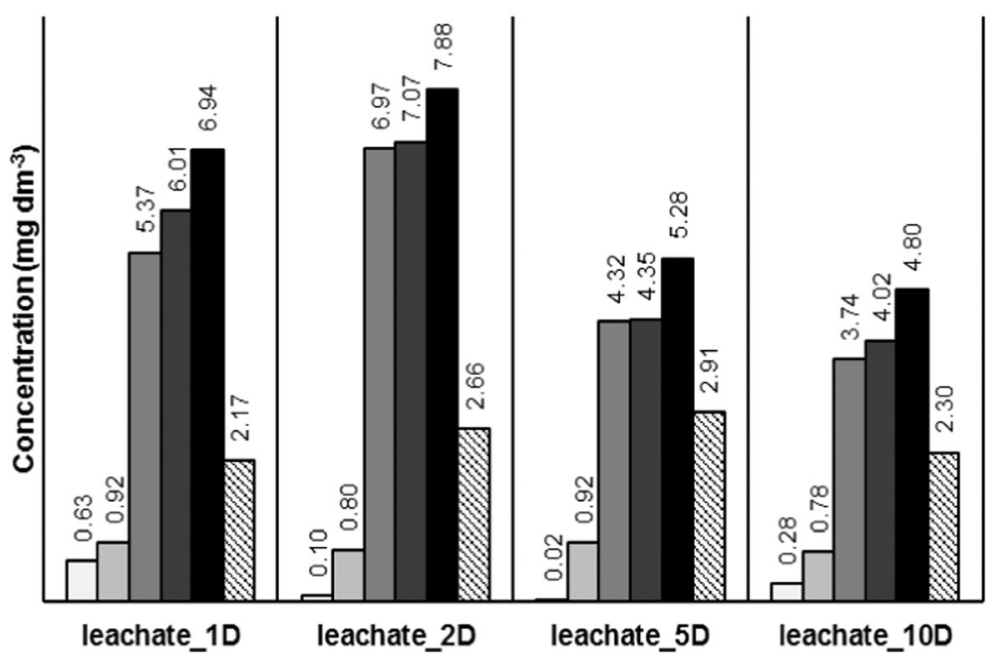

leachates $\left(0.78-0.92 \mathrm{mg} \mathrm{dm}^{-3}\right)$. However, the presence of nitrite nitrogen $\left(\mathrm{NO}_{2}{ }^{-}\right)$was not found in any of the leachates.

Nitrogen usually occurs in bark in higher amounts than in wood and - next to $\mathrm{C}, \mathrm{O}$, and $\mathrm{H}$ - is the main component of wood biomass (Filbakk et al. 2011; Chandrasekaran et al. 2012; Vassilev et al. 2012). Studies show that nitrogen constitutes $0.40-0.64 \%$ dry basis of pine bark. Its occurrence is disadvantageous from the point of view of biomass combustion, because nitrogen is responsible for the occurrence of harmful gas $\left(\mathrm{NO}_{x}\right)$ and aerosol emissions, photochemical smog, and high-temperature corrosion and for the formation of nitric acid (Mace et al. 2003; Filbakk et al. 2011; Vamvuka and Sfakiotakis 2011; Vassilev et al. 2015). On the other hand, nitrogen is a valuable nutrient, thanks to which leachates containing it in its composition can be used to enrich the soil or crop plants. Therefore, discharge of leachates with high concentration of nitrogen to water may contribute to the appearance of eutrophic conditions in the receiver (Vassilev et al. 2015). It is estimated that nitrogen can be leached from biomass in about $37 \%$, and its mobile and water-soluble form is nitrate nitrogen (Vassilev et al. 2012; Jiang et al. 2013). In addition, small quantities of ammonium ions (NH4+) are leached from the pine bark, as evidenced by their presence in the analyzed leachates. Nitrogen is not a component of the mineral fraction (it is not present in the ashes), but it may be associated with the mineral fraction in the form of $\mathrm{NO}_{3}{ }^{-}$and $\mathrm{NH}_{4}{ }^{+}$ions (Werkelin et al. 2010; Miranda et al. 2012). The literature data indicate the efficiency of nitrogen removal during the leaching of biomass with distilled water (Jiang et al. 2013). The presence of high amounts of the organic forms of nitrogen in the leachates suggests that the organic compounds are removed by using distilled water and that organic nitrogen is the dominant form of this element in biomass. Among the organic compounds that can be leached out of the biomass and enrich the leachates in nitrogen, proteins, amino acids (mainly arginine, which is well soluble in water, and glutamine), nucleic acids, humic acids, and other organic acids, glycosides and lipids can be distinguished (Nordin et al. 2001; Valentín et al. 2010; Yu et al. 2014). The content of nitrogen in wood biomass is strictly dependent on its concentration in the soil and will be accumulated to a greater extent by plants growing on soils fertilized with the use of nitrogen (Nordin et al. 2001). Nitrogen and phosphorus are the elements most often limiting the functioning of the terrestrial ecosystem (Liu et al. 2012). Nitrogen can also support the process of humification of soils (Prescott 2010).

\subsection{Concentration of Total Phosphorus in the Leachates}

Phosphorus (next to the nitrogen) is an essential and irreplaceable biogenic component for the growth of biomass (Tan and Lagerkvist 2011; Bawiec 2018). The 
analysis of the data (Fig. 4) shows that in the first three leachates (after 1 day, 2 days, and 5 days of leaching), the concentration of total phosphorus increases with the time of leaching, respectively, $2.17 \mathrm{mg} \mathrm{dm}^{-3} \rightarrow$ $2.66 \mathrm{mg} \mathrm{dm}^{-3} \rightarrow 2.91 \mathrm{mg} \mathrm{dm}^{-3}$. Only in the last leachate, after 10 days of leaching, the concentration of total phosphorus slightly decreased $\left(2.30 \mathrm{mg} \mathrm{dm}^{-3}\right)$. The study conducted by Tan and Lagerkvist (2011) also indicates that during the first week of leaching the concentration of phosphorus in the leachate increased, then it began to gradually decrease, and reached the minimum value of $0.01 \mathrm{mg} \mathrm{dm}^{-3}$ after 3 weeks of leaching.

Phosphorus is leached from biomass in the form of phosphates, oxides $\left(\mathrm{P}_{2} \mathrm{O}_{5}\right)$, salts $\left(\mathrm{KH}_{2} \mathrm{PO}_{4}\right)$, and organic compounds such as esters or pyrophosphates (Werkelin et al. 2010; Vamvuka and Sfakiotakis 2011; Vassilev et al. 2015). It is leached with water with high efficiency (about 65\%) (Werkelin et al. 2010). The presence of phosphorus in biomass contributes to a decrease in the temperature of ashes fouling. The intensity of phosphorus removal from the biomass increases along with moisture content and decrease in the pH (Filbakk et al. 2011; Tan and Lagerkvist 2011; Vassilev et al. 2015). Phosphorus, like other water-soluble components, can be lost already at the stage of biomass growth and storage (Vassilev et al. 2015). The leachates after the leaching of pine bark, which contain phosphorus, can enrich soils in the old ecosystems where the natural sources of this element have been exhausted. In the forest soils (with a high concentration of organic matter), phosphorus displays a key role in the development of microorganisms by affecting the increase in bioaccumulation of carbon (Liu et al. 2012). Phosphorus and nitrogen have been discussed in detail in the analysis of the results due to their importance in the case of using pine bark as a substrate in the technology of algal cultivation (this issue concerns separate studies conducted by the author).

\subsection{Total Organic Carbon in the Leachates}

Figure 5 shows the changes in the content of the volatiles and TOC in the distilled water used for the leaching of the pine bark and in the leachates after different times of leaching. TOC is the most comprehensive parameter which is used to quantify the content of dissolved organic matter (DOM) in the aquatic environment. It is often equated with the total natural organic matter (NOM) (Leenheer and Croué 2003). An unfavorable phenomenon that occurs during the leaching of biomass is partial loss of organic compounds, mainly sugars (cellulose and hemicellulose) but also lipids, organic acids, alcohols, proteins, tannins, and other extractives which are present in the liquid phase of biomass. This contributes to a change in the chemical composition, weight, and heating value reduction, as well as delays the process of carbonization of biomass during pyrolysis or combustion (Liu and Bi 2011; Deng et al. 2013; Jiang et al. 2013; Yu et al. 2014). Significantly higher values
Fig. 5 The concentration of TOC in the leachates after different times of leaching of pine bark with distilled water

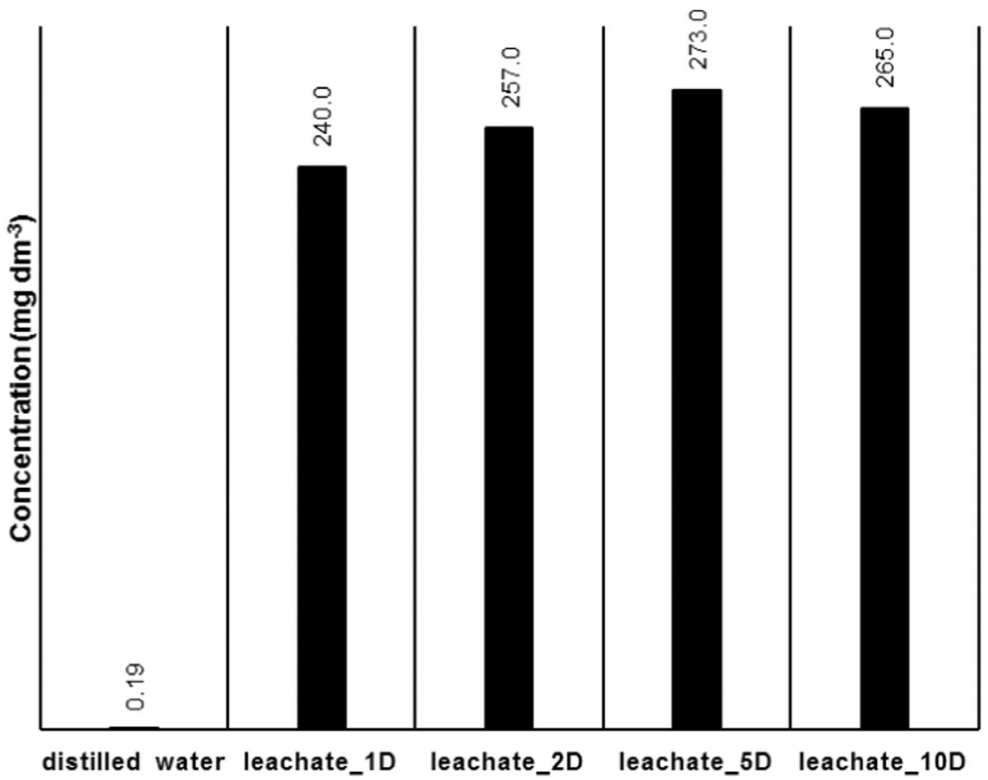


of TOC for the leachate samples compared to the distilled water indicate the occurrence of this phenomenon in the conducted experiment.

According to the researchers, the organic compounds leached during the leaching of pine bark with water are mainly sugars (hemicellulose and derivatives of cellulose), lipids, organic acids (phenolic acid, oleic acid, linolenic and linoleic acids, and other fatty acids), resin compounds, alcohols, oils, polyphenols, proteins, tannins, flavonoids, sterols, and others (Valentín et al. 2010; Deng et al. 2013; Schomakers et al. 2014; Yu et al. 2014). According to the author, as a result of atmospheric pollution, such organic pollutants as polycyclic aromatic hydrocarbons (PAHs), dioxins, or furans can penetrate the bark structure. These compounds are then extracted during the leaching process. An important group of organic compounds leached from biomass are humic compounds (Leenheer and Croué 2003; Schomakers et al. 2014) which influence, among others, the intensity of the color of the leachates formed during the leaching process. These compounds also contribute to the change of color mainly in surface waters (Świderska-Bróż and Kowal 2009). The presence of the organic compounds in the leachates after the leaching of biomass hinders their subsequent purification due to the high values of the BOD and COD indicators ( $Y u$ et al. 2014). However, due to the high content of the extractives, the leachates after the leaching of biomass are a valuable material for obtaining sugars, tannins, terpenes, resins, dyes, lipids, oils, organic acids, proteins, or inorganic salts (Vassilev et al. 2012; Kalogiannis et al. 2015; Vassilev et al. 2015; Chen et al. 2018). The organic compounds in the environment affect the values of the redox potential and $\mathrm{pH}$, as well as migration of many elements. Organic compounds are also involved in the processes of sorption and ion exchange (Świderska-Bróż and Kowal 2009).

Together with the organic compounds, alkali metals and alkali earth metals, as well as harmful elements such as Ag, $\mathrm{Cd}, \mathrm{Cl}, \mathrm{Cr}, \mathrm{Cu}, \mathrm{Hg}, \mathrm{Mn}, \mathrm{Ni}, \mathrm{Se}$, and $\mathrm{Zn}$ which are bound with them, may also pass to the water (Werkelin et al. 2010; Vassilev et al. 2012; Vassilev et al. 2015; Vassilev and Vassileva 2016; Han et al. 2018). In water containing organic compounds and heavy metal ions, organometallic compounds are formed. This process limits the mobility of these elements (Świderska-Bróż and Kowal 2009).

The literature data show that with increasing time of leaching, the amount of the leached organic compounds also increases (Liu and Bi 2011). In the case of the analyzed leachates, a similar relation can be found (Fig. 5). However, in this case the maximum concentration of total organic carbon was reached after 5 days of leaching ( $273 \mathrm{mg} \mathrm{dm}^{-3}$ ), while after 10 days of leaching a decrease in the TOC value was noted $\left(265 \mathrm{mg} \mathrm{dm}^{-3}\right)$. In the last leachate, the lowest concentrations of total nitrogen and total phosphorus (Fig. 4) contained in the organic compounds were also observed. It is likely that the low TOC value in the leachate after 10 days of leaching corresponds to the beginning of the processes of natural degradation of the organic matter and its mineralization through biochemical transformation. The processes of the adsorption of DOM on bark particles suspended in water, coagulation, and flocculation may also contribute to the reduction of dissolved organic compounds. During these processes, the dissolved organic substances $(<1 \mathrm{~nm})$ pass into the colloidal or suspended fraction and could remain in the concentrate during the filtration of the sample after the leaching process.

Despite the loss of certain amounts of the organic compounds during the leaching with water $(0.72-0.82 \%$ dry weight), it is a solvent which significantly limits the leaching of those compounds from biomass, compared to acid leaching. Due to the intensive hydrolysis of the chains of hemicellulose, cellulose, and lignin, acid leaching is much more effective with respect to the removal of organic compounds (Springer and Harris 1982; Liu and Bi 2011; Kalogiannis et al. 2015).

\subsection{ICP-OES Analysis of Crude Bark and the Leachates}

Table 3 presents the elements that occur in the analyzed samples of the leachates and the crude pine bark. From the wide spectrum of 25 elements (measuring range of device), the presence of 11 of them $(\mathrm{Ag}, \mathrm{Al}, \mathrm{B}, \mathrm{Ca}, \mathrm{Cu}, \mathrm{Fe}, \mathrm{K}, \mathrm{Mg}$, $\mathrm{Mn}, \mathrm{Na}$, and $\mathrm{Zn}$ ) was observed. Some of these elements, as components of the organic or inorganic compounds, may have a negative impact on the natural environment, these being $\mathrm{Ag}, \mathrm{Al}, \mathrm{Cu}, \mathrm{Mn}$, and $\mathrm{Zn}$. They cause, among others, an increase in soil salinity, contamination of groundwater, and intoxication of flora and fauna during the processing of biomass, utilization of the ashes (Chandrasekaran et al. 2012; Vassilev et al. 2015; Vassilev et al. 2014; Han et al. 2018; Kubicz et al. 2018), and leaching of biomass with rainwater. In addition to the potential environmental risk, inorganic compounds contained in biomass may pose difficulties during the thermal conversion of biomass (Wigley et al. 2016). Some elements, in the optimal concentrations, 
Table 3 The elemental composition of the leachates (non-mineralized and mineralized) and the crude bark (mg $\mathrm{g}_{\mathrm{DW}}{ }^{-1}$ ) present in the samples during the ICP-OES analysis (n/d-not detected)

\begin{tabular}{lllllllllll}
\hline Cations & DW $^{\mathrm{b}}$ & L1D $^{\mathrm{c}}$ & L2D $^{\mathrm{c}}$ & L5D $^{\mathrm{c}}$ & L10D $^{\mathrm{c}}$ & ML1D $^{\mathrm{d}}$ & ML2D $^{\mathrm{d}}$ & ML5D $^{\mathrm{d}}$ & ML10D $^{\mathrm{d}}$ & CB $^{\mathrm{e}}$ \\
\hline $\mathrm{Cu}$ & 0.002 & 0.010 & 0.005 & $0.014^{\mathrm{a}}$ & 0.010 & 0.025 & 0.071 & $0.082^{\mathrm{a}}$ & 0.012 & 2.916 \\
$\mathrm{Ag}$ & $\mathrm{n} / \mathrm{d}$ & $\mathrm{n} / \mathrm{d}$ & $\mathrm{n} / \mathrm{d}$ & $\mathrm{n} / \mathrm{d}$ & $\mathrm{n} / \mathrm{d}$ & $0.002^{\mathrm{a}}$ & $0.002^{\mathrm{a}}$ & 0.001 & 0.001 & 0.012 \\
$\mathrm{Al}$ & 0.007 & 0.071 & 0.072 & $0.089^{\mathrm{a}}$ & 0.082 & 0.068 & $0.075^{\mathrm{a}}$ & 0.049 & 0.053 & 0.610 \\
$\mathrm{~B}$ & $\mathrm{n} / \mathrm{d}$ & $0.006^{\mathrm{a}}$ & 0.005 & 0.005 & $0.006^{\mathrm{a}}$ & $0.009^{\mathrm{a}}$ & 0.005 & 0.005 & 0.005 & 0.428 \\
$\mathrm{Ca}$ & $\mathrm{n} / \mathrm{d}$ & $0.392^{\mathrm{a}}$ & 0.324 & 0.292 & 0.307 & $0.151^{\mathrm{a}}$ & 0.146 & 0.106 & 0.133 & 2.599 \\
$\mathrm{Fe}$ & $\mathrm{n} / \mathrm{d}$ & 0.004 & 0.002 & $0.006^{\mathrm{a}}$ & $0.006^{\mathrm{a}}$ & $0.046^{\mathrm{a}}$ & 0.033 & 0.006 & 0.011 & 0.226 \\
$\mathrm{Mg}$ & $\mathrm{n} / \mathrm{d}$ & 0.105 & 0.093 & 0.114 & $0.126^{\mathrm{a}}$ & 0.123 & $0.130^{\mathrm{a}}$ & 0.097 & 0.125 & 0.330 \\
$\mathrm{Mn}$ & $\mathrm{n} / \mathrm{d}$ & 0.015 & 0.016 & 0.019 & $0.020^{\mathrm{a}}$ & 0.014 & 0.016 & 0.015 & $0.020^{\mathrm{a}}$ & 0.159 \\
$\mathrm{Zn}$ & $\mathrm{n} / \mathrm{d}$ & 0.009 & 0.006 & $0.010^{\mathrm{a}}$ & 0.009 & 0.011 & $0.027^{\mathrm{a}}$ & 0.016 & 0.012 & 0.129 \\
$\mathrm{~K}$ & 0.011 & 0.741 & 0.773 & $0.833^{\mathrm{a}}$ & 0.767 & 0.835 & $0.849^{\mathrm{a}}$ & 0.738 & 0.803 & 2.954 \\
$\mathrm{Na}$ & $\mathrm{n} / \mathrm{d}$ & 0.108 & 0.080 & $0.083^{\mathrm{a}}$ & 0.080 & 0.252 & $0.265^{\mathrm{a}}$ & 0.135 & 0.101 & 1.109 \\
\hline
\end{tabular}

${ }^{a}$ The highest value of element in the leachate

${ }^{\mathrm{b}}$ Distilled water sample

${ }^{\mathrm{c}}$ Non-mineralized leachates

${ }^{\mathrm{d}}$ Mineralized leachates

${ }^{\mathrm{e}}$ Crude bark sample

can play a positive role in the environment. The examples are $\mathrm{Al}, \mathrm{Ca}, \mathrm{K}, \mathrm{Fe}, \mathrm{Mg}$, and $\mathrm{Na}$, which together with nitrogen, phosphorus, silica, and organic matter make it possible to use the leachates after the leaching process to fertilize the soil and enrich it with ingredients necessary for plants (Jensen et al. 2001a; Deng et al. 2013; Vassilev et al. 2015). Heavy metals collected by roots of trees are accumulated in the bark; ipso facto, it contains significantly higher amounts of these elements than wood. In addition, it is stated that coniferous trees contain more heavy metals than deciduous trees (Chandrasekaran et al. 2012).

In the crude pine bark (CB) used in the study, elements such as $\mathrm{Ca}\left(2.599 \mathrm{mg}_{\mathrm{DW}}{ }^{-1}\right), \mathrm{Cu}$
(2.916 $\left.\mathrm{mg} \mathrm{g}_{\mathrm{DW}}{ }^{-1}\right), \mathrm{K}\left(2.954 \mathrm{mg} \mathrm{g}_{\mathrm{DW}}{ }^{-1}\right), \mathrm{Na}$ (1.109 $\left.\mathrm{mg} \mathrm{g}_{\mathrm{DW}}{ }^{-1}\right)$, and $\mathrm{Al}\left(0.610 \mathrm{mg} \mathrm{g}_{\mathrm{DW}}{ }^{-1}\right)$ mainly occurred. All elements present in the crude bark (expect $\mathrm{Ag}$ ) in smaller or larger concentrations in the nonmineralized leachates occurred. In the case of pine bark, aluminum ( $\mathrm{Al}$ ) is of particular importance, as in the biomass of this species it can be found in more than $70 \%$ in the form of the water-soluble hydroxide $\mathrm{Al}(\mathrm{OH})_{3}$ (Werkelin et al. 2010). Other elements occurred in crude bark in much smaller quantities: B (0.428 $\left.\mathrm{mg} \mathrm{g}_{\mathrm{DW}}{ }^{-1}\right), \mathrm{Mg}\left(0.330 \mathrm{mg} \mathrm{g}_{\mathrm{DW}}{ }^{-1}\right), \mathrm{Fe}$ (0.226 mg $\left.\mathrm{g}_{\mathrm{DW}}{ }^{-1}\right), \mathrm{Zn}\left(0.129 \mathrm{mg} \mathrm{g}_{\mathrm{DW}}{ }^{-1}\right), \mathrm{Mn}$ (0.159 $\left.\mathrm{mg} \mathrm{g}_{\mathrm{DW}}{ }^{-1}\right)$, and $\mathrm{Ag}\left(0.012 \mathrm{mg} \mathrm{g}_{\mathrm{DW}}{ }^{-1}\right)$.
Fig. 6 The average concentrations of the elements leached form the pine bark during the leaching with distilled water

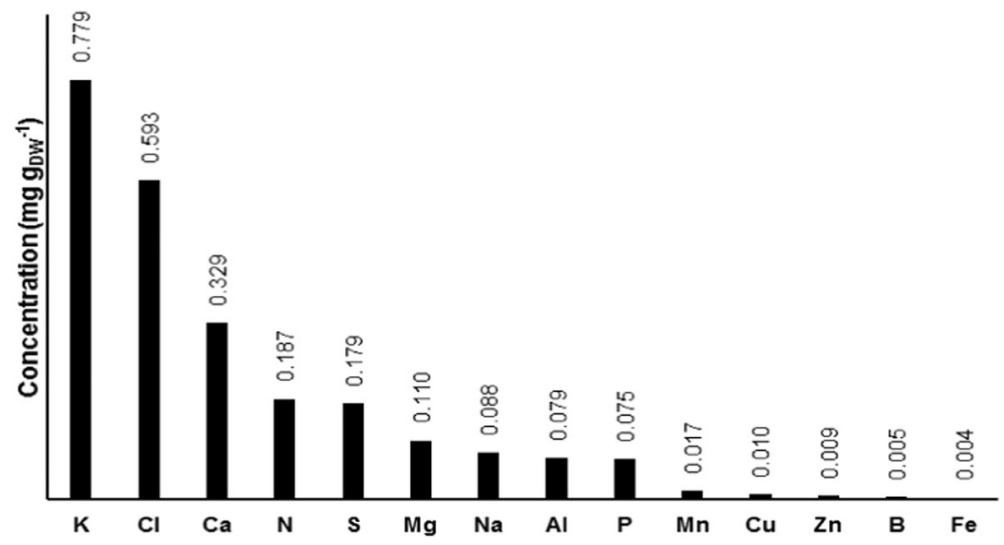


Potassium (0.741-0.833 $\left.\mathrm{mg} \mathrm{g}_{\mathrm{DW}}{ }^{-1}\right)$, calcium (0.292-0.392 $\left.\mathrm{mg} \mathrm{g}_{\mathrm{DW}}{ }^{-1}\right)$, magnesium (0.093$\left.0.126 \mathrm{mg} \mathrm{g}_{\mathrm{DW}}{ }^{-1}\right)$, sodium $\left(0.080-0.108 \mathrm{mg} \mathrm{g}_{\mathrm{DW}}{ }^{-1}\right)$, and aluminum $\left(0.071-0.089 \mathrm{mg} \mathrm{g}_{\mathrm{DW}}{ }^{-1}\right)$ were leached directly from the bark in significant amounts. Their concentrations in non-mineralized leachates were maintained at a relatively constant level along with increasing time of the leaching. The other elements (B, Cu, Fe, Mn, and $\mathrm{Zn}$ ) occurred in the non-mineralized leachates in significantly lower quantities (0.002-0.020 $\mathrm{mg} \mathrm{g}_{\mathrm{DW}}{ }^{-1}$ ), and the time of leaching also did not affect the increase in their concentration in the distilled water. The exception was manganese, whose concentration increased from $0.015 \mathrm{mg} \mathrm{g}_{\mathrm{DW}}{ }^{-1}$ after the first day of leaching to $0.020 \mathrm{mg} \mathrm{g}_{\mathrm{DW}}{ }^{-1}$ after 10 days of leaching, but this increase was insignificant. Silver ions were not detected in the non-mineralized leachates, but they were found in trace amounts in the mineralized leachates (0.001$0.002 \mathrm{mg} \mathrm{g}_{\mathrm{DW}}{ }^{-1}$ ). The elements that occurred in high concentrations in the leachates after the leaching of pine bark belong to the group of the most mobile elementary components of biomass; hence, they are extensively removed from the biomass (Vassilev and Vassileva 2016). The alkali earth metals ( $\mathrm{Ca}$ and $\mathrm{Mg}$ ) may exist in biomass in the form of water-soluble and bioavailable salts: chlorides, phosphates, sulfates, oxalates, nitrates, and carbonates, as well as amorphous compounds with organic or inorganic nature (Vassilev et al. 2015). Based on Tables 2 and 3, the average concentrations of the individual elementary components in the non-mineralized leachates (L1D, ..., L10D) were determined. They were arranged in a downward order in Fig. 6.

A characteristic feature of the mineralized leachates (ML1D, ..., ML10D) are higher concentrations of some elements compared to the non-mineralized leachates. The examples are $\mathrm{Cu}, \mathrm{Zn}, \mathrm{Fe}$, and $\mathrm{Na}$ which in mineralized leachates are present in 2-, 3-, and even 20-fold higher concentrations than in non-mineralized leachates. This proves the presence of these elements in sparingly soluble compounds that passed into the water together with pieces of bark, suspensions, or organic and inorganic compounds. Due to the mineralization process (mixture of the acids and high temperature), the elements have passed from the sparingly soluble compounds into the solution (Güney and Elik 2017). The mineralized leachates after 1 day of leaching had the highest concentrations of $\mathrm{B}, \mathrm{Ca}$, and $\mathrm{Fe}$. However, the most elements from the mineralized leachates went to the solution after 2 days of the leaching. In this case, the highest concentrations were noted for $\mathrm{Al}, \mathrm{Mg}, \mathrm{Zn}, \mathrm{K}$, and $\mathrm{Na}$. There is also a large share of volatile matter in the dry residue of the leachate (Table 2), which suggests that the elements released after the mineralization process were mostly associated with the organic fraction. The highest concentrations of copper $\left(0.082 \mathrm{mg} \mathrm{g}_{\mathrm{DW}}{ }^{-1}\right)$ and manganese $\left(0.020 \mathrm{mg} \mathrm{g}_{\mathrm{DW}}{ }^{-1}\right)$ were present in the mineralized leachates after 5 and 10 days of leaching, respectively. It can be found that the highest concentrations of most of the leached elements occurred after 5 and 10 days of leaching in the non-mineralized leachates (bolded values in Table 3), whereas the highest concentrations of the elements in the mineralized leachates were noted after 1 and 2 days of leaching (bolded values in Table 3 ). It is clearly visible that the concentration of calcium in each of the four tested samples decreased over two times after the mineralization of the leachates. This is related to the conditions of carrying out the mineralization process. Due to the high temperature and the mixture of acids (in the presence of $\mathrm{H}_{2} \mathrm{SO}_{4}$ ), precipitation of free calcium ions in the form of the sparingly soluble salts occurred and they have not been registered by the ICP-OES apparatus.

\section{Conclusions}

On the basis of the conducted studies, the following conclusions were determined:

- Long-term leaching of biomass with water affects some physico-chemical parameters of the formed leachates.

- Along with the extension of the leaching time, values for electrical conductivity, concentration of mineral fraction (ashes), concentration of volatile matter, and concentration of total organic carbon significantly increased in the leachates (increase in concentration of TOC up to the 5th day of the leaching).

- There was no influence of long-term leaching on a significant change in the value of $\mathrm{pH}$ (except of the first day of the leaching). In addition, no linear relationship between the extension of the leaching time and the increase in the concentration of chlorides, sulfates, nitrogen, phosphorus, and other elements was observed.

- Among the elements extracted from pine bark, $\mathrm{K}$, followed by $\mathrm{Cl}, \mathrm{Ca}, \mathrm{N}, \mathrm{S}, \mathrm{Mg}, \mathrm{Na}, \mathrm{Al}$ and $\mathrm{P}$, had the 
largest share in the leachates. The other analyzed elements $(\mathrm{Mn}, \mathrm{Cu}, \mathrm{Zn}, \mathrm{B}$, and $\mathrm{Fe}$ ) were found in trace amounts.

- Under natural conditions, the biomass leaching process may enrich the aquatic and terrestrial ecosystems with nutrients and, at the same time, contribute to the spread of pollutants.

- Knowledge about long-term effects of water on other species of biomass in natural conditions will allow to estimate the risk of environmental pollution caused by the formed leachates (surface runoff) in the areas of vegetation communities. In addition, it will help in determining appropriate rules of the storage of biomass for technological purposes limiting the extraction of valuable as well as harmful components.

\section{Compliance with Ethical Standards}

Conflict of Interest The author declares that he has no conflict of interest.

Open Access This article is distributed under the terms of the Creative Commons Attribution 4.0 International License (http:// creativecommons.org/licenses/by/4.0/), which permits unrestricted use, distribution, and reproduction in any medium, provided you give appropriate credit to the original author(s) and the source, provide a link to the Creative Commons license, and indicate if changes were made.

\section{References}

Asadieraghi, M., \& Wan Daud, W. M. A. (2014). Characterization of lignocellulosic biomass thermal degradation and physiochemical structure: effects of demineralization by diverse acid solutions. Energy Conversion and Management, 82, 71-82.

Bawiec, A. (2018). Efficiency of nitrogen and phosphorus compounds removal in hydroponic wastewater treatment plant. Environmental Technology, 1-11. https://doi.org/10.1080 /09593330.2018.1436595.

Boelee, N. C., Temmink, H., Janssen, M., Buisman, C. J. N., \& Wijffels, R. H. (2011). Nitrogen and phosphorus removal from municipal wastewater effluent using microalgal biofilms. Water Research, 45, 5925-5933.

Chandrasekaran, S. R., Hopke, P. K., Rector, L., Allen, G., \& Lin, L. (2012). Chemical composition of wood chips and wood pellets. Energy \& Fuels, 26, 4932-4937.
Chen, J., Adjallé, K., Barnabé, S., Perrier, M., \& Paris, J. (2018). Mechanical and thermal pretreatment processes for increasing sugar production from woody biomass via enzymatic hydrolysis. Waste and Biomass Valorization, 1-9. https://doi.org/10.1007/s12649-018-0217-x.

Deng, L., Zhang, T., \& Che, D. (2013). Effect of water washing on fuel properties, pyrolysis and combustion characteristics, and ash fusibility of biomass. Fuel Processing Technology, 106, 712-720.

Eom, I. Y., Kim, J. Y., Kim, T. S., Lee, S. M., Choi, D., Choi, I. G., \& Choi, J. W. (2012). Effect of essential inorganic metals on primary thermal degradation of lignocellulosic biomass. Bioresource Technology, 104, 687-694.

Filbakk, T., Jirjis, R., Nurmi, J., \& Høibø, O. (2011). The effect of bark content on quality parameters of Scots pine (Pinus sylvestris L.) pellets. Biomass and Bioenergy, 35, 33423349.

Food and Agriculture Organization of the United Nations. (2016). Global Forest Resources Assessment 2015: How are the world's forests changing? (Second ed.). Rome.

Garbowski, T., Bawiec, A., Pulikowski, K., \& Wiercik, P. (2017). Algae proliferation on substrates immersed in biologically treated sewage. Journal of Ecological Engineering, 18, 9098.

Güney, M., \& Elik, A. (2017). Comparison of probe with bath ultrasonic leaching procedures for preparation to heavy metal analysis of bio-collectors prior to atomic absorption spectrometry. Communications in Soil Science and Plant Analysis, 48, 1741-1752.

Han, Z., Guo, Z., Zhang, Y., Xiao, X., Xu, Z., \& Sun, Y. (2018). Pyrolysis characteristics of biomass impregnated with cadmium, copper and lead: influence and distribution. Waste Biomass Valor, 9, 1223-1230.

Jensen, P. A., Sander, B., \& Dam-Johansen, K. (2001a). Pretreatment of straw for power production by pyrolysis and char wash. Biomass and Bioenergy, 20, 431-446.

Jensen, P. A., Sander, B., \& Dam-Johansen, K. (2001b). Removal of $\mathrm{K}$ and $\mathrm{Cl}$ by leaching of straw char. Biomass and Bioenergy, 20, 447-457.

Jiang, L., Hu, S., Sun, L., Su, S., Xu, K., He, L., \& Xiang, J. (2013). Influence of different demineralization treatments on physicochemical structure and thermal degradation of biomass. Bioresource Technology, 146, 254-260.

Kalogiannis, K. G., Stefanidis, S., Marianou, A., Michailof, C., Kalogianni, A., \& Lappas, A. (2015). Lignocellulosic biomass fractionation as a pretreatment step for production of fuels and green chemicals. Waste and Biomass Valorization, 6, 781-790.

Klasnja, B., Kopitovic, S., \& Orlovic, S. (2002). Wood and bark of some poplar and willow clones as fuelwood. Biomass and Bioenergy, 23, 427-432.

Kröppl, M., \& Lanzerstorfer, C. (2013). Acidic extraction and precipitation of heavy metals from biomass incinerator cyclone fly ash. E3S Web of Conferences, 1, 16007.

Kubicz, J., Pawełczyk, A., \& Lochyński, P. (2018). Environmental health risk posed by contamination of the individual water wells. Chemosphere, 208, 247-256. 
Leenheer, J. A., \& Croué, J.-P. (2003). Peer reviewed: characterizing aquatic dissolved organic matter. Environmental Science \& Technology, 37, 18A-26A.

Liu, X., \& Bi, X. T. (2011). Removal of inorganic constituents from pine barks and switchgrass. Fuel Processing Technology, 92, 1273-1279.

Liu, L., Gundersen, P., Zhang, T., \& Moa, J. (2012). Effects of phosphorus addition on soil microbial biomass and community composition in three forest types in tropical China. Soil Biology \& Biochemistry, 44, 31-38.

Mace, K. A., Artaxo, P., \& Duce, R. A. (2003). Water-soluble organic nitrogen in Amazon Basin aerosols during the dry (biomass burning) and wet seasons. Journal of Geophysical Research, 108(D16), 1-10.

Miranda, I., Gominho, J., Mirra, I., \& Pereira, H. (2012). Chemical characterization of barks from Picea abies and Pinus sylvestris after fractioning into different particle sizes. Industrial Crops and Products, 36, 395-400.

Moreno-Casas, P., Aral, H., Vecchio-Sadus, A. (2009). Environmental impact and toxicology of sulphate (conference paper). https://www.researchgate. net/publication/282293070_ENVIRONMENTAL_ IMPACT_AND_TOXICOLŌGY_OF_SULPHATE. Accessed $\overline{23}$ June $\overline{2} 019$.

Nordin, A., Uggla, C., \& Näsholm, T. (2001). Nitrogen forms in bark, wood and foliage of nitrogen-fertilized Pinus sylvestris. Tree Physiology, 21, 59-64.

PN-73/C04576-14. (1973). Water and wastewater. Determination of total nitrogen by calculation. The polish Committee for Standardization. in Polish.

PN-82C-04576/08. (1982). Water and wastewater. Determination of nitrate nitrogen by spectrophotometric method with sodium salicylate. The Polish Committee for Standardization. in Polish.

PN-EN 25663:2001. (2001). Water quality. Determination of Kjeldahl nitrogen. Method after mineralization with selenium. The Polish Committee for Standardization. in Polish.

PN-EN 26777:1999. (1999). Water quality. Determination of nitrite. Molecular absorption spectrometric method. The Polish Committee for Standardization. in Polish.

PN-EN 27888:1999. (1999). Water quality. Determination of electrical conductivity. The Polish Committee for Standardization. in Polish.

PN-EN ISO 10523:2012. (2012). Water quality. Determination of $\mathrm{pH}$. The Polish Committee for Standardization. in Polish.

PN-EN ISO 6878:2006. (2006). Water quality. Determination of phosphorus. Ammonium molybdate spectrometric method. The Polish Committee for Standardization. in Polish.

PN-ISO 7150-1:2002. (2002). Water quality. Determination of ammonium. Part 1: Manual spectrometric method. The Polish Committee for Standardization. In Polish.

PN-ISO 9280:2002. (2002). Water quality. Determination of sulfate. Gravimetric method using barium chloride. The Polish Committee for Standardization. in Polish.

PN-ISO 9297:1994. (1994). Water quality. Determination of chloride. Silver nitrate titration with chromate indicator (Mohr's method). The Polish Committee for Standardization. in Polish.
Prajapati, S. K., Kaushik, P., Malik, A., \& Vijay, V. K. (2013). Phycoremediation coupled production of algal biomass, harvesting and anaerobic digestion: possibilities and challenges. Biotechnology Advances, 31, 1408-1425.

Prescott, C. E. (2010). Litter decomposition: what controls it and how can we alter it to sequester more carbon in forest soils? Biogeochemistry, 101, 133-149.

Raczyk-Stanisławiak, U., Świetlik, J., \& Nawrocki, J. (2005). Effect of chlorine, chlorine dioxide and ozone on the biological stability of water. Ochrona Środowiska, 27(3), 33-37. In polish.

Rawat, I., Ranjith Kumar, R., Mutanda, T., \& Bux, F. (2011). Dual role of microalgae: phycoremediation of domestic wastewater and biomass production for sustainable biofuels production. Applied Energy, 88, 3411-3424.

Schomakers, J., Mentler, A., \& Mayer, H. (2014). Determination of dissolved organic carbon in soils with UV spectroscopy, ultrasonic dispersion pre-treatment and separation with size exclusion chromatography. Spanish Journal of Soil Science, 4, 127-142.

Shorohova, E., \& Kapitsa, E. (2014). Mineralization and fragmentation rates of bark attached to logs in a northern boreal forest. Forest Ecology and Management, 315, 185-190.

Springer, E. L., \& Harris, J. F. (1982). Pre-hydrolysis of aspen wood with water and with dilute aqueous sulfuric-acid (Vol. 85, pp. R152-R154). Svensk Papperstidning-Nordisk Cellulosa.

Štrusowá, M., Žifčáková, L., Leigh, M. B., Burgess, R., \& Baldrian, P. (2012). Cellulose utilization in forest litter and soil: identification of bacterial and fungal decomposers. FEMS Microbiology Ecology, 80(3), 735-746.

Świderska-Bróż, M., \& Kowal, A.L. (2009). Oczyszczanie wody. Podstawy teoretyczne i technologiczne, procesy i urządzenia. Warszawa: Wydawnictwo Naukowe PWN. In polish.

Tan, Z., \& Lagerkvist, A. (2011). Phosphorus recovery from the biomass ash: a review. Renewable \& Sustainable Energy Reviews, 15, 3588-3602.

Valentín, L., Kluczek-Turpeinen, B., Willför, S., Hemming, J., Hatakka, A., Steffen, K., \& Tuomela, M. (2010). Scots pine (Pinus sylvestris) bark composition and degradation by fungi: potential substrate for bioremediation. Bioresource Technology, 101, 2203-2209.

Vamvuka, D., \& Sfakiotakis, S. (2011). Effects of heating rate and water leaching of perennial energy crops on pyrolysis characteristics and kinetics. Renewable Energy, 36, 2433-2439.

Vassilev, S. V., \& Vassileva, C. G. (2016). Composition, properties and challenges of algae biomass for biofuel application: an overview. Fuel, 181, 1-33.

Vassilev, S. V., Baxter, D., Andersen, L. K., Vassileva, C. G., \& Morgan, T. J. (2012). An overview of the organic and inorganic phase composition of biomass. Fuel, 94, 1-33.

Vassilev, S. V., Vassileva, C. G., \& Baxter, D. (2014). Trace element concentrations and associations in some biomass ashes. Fuel, 129, 292-313.

Vassilev, S. V., Vassileva, C. G., \& Vassilev, V. S. (2015). Advantages and disadvantages of composition and properties of biomass in comparison with coal: an overview. Fuel, 158, 330-350. 
Werkelin, J., Skrifvars, B.-J., Zevenhoven, M., Holmbom, B., \& Hupa, M. (2010). Chemical forms of ash-forming elements in woody biomass fuels. Fuel, 89, 481-493.

Wigley, T., Yip, A. C. K., \& Pang, S. (2016). Pretreating biomass via demineralisation and torrefaction to improve the quality of crude pyrolysis oil. Energy, 109, 481-494.

Xie, S., Ma, Y., Strong, P. J., \& Clarke, W. P. (2015). Fluctuation of dissolved heavy metal concentrations in the leachate from anaerobic digestion of municipal solid waste in commercial scale landfill bioreactors: the effect of $\mathrm{pH}$ and associated mechanisms. Journal of Hazardous Materials, 299, 577-583.
Yu, C., Thy, P., Wang, L., Anderson, S. N., Vandergheynst, J. S., Upadhyaya, S. K., \& Jenkins, B. M. (2014). Influence of leaching pretreatment on fuel properties of biomass. Fuel Processing Technology, 128, 43-53.

Publisher's Note Springer Nature remains neutral with regard to jurisdictional claims in published maps and institutional affiliations. 